endeavor to learn more, then you may rightly say that yours is indecd a learned profession. You will then enjoy all the delights that learning and investigation bring. You will be constantly moving forward, reaching new points of interest, and will be contributing to the grencral advance of medicine.

During your tutelage here you have learned many inportant facts and have had thorough training in the practical work of a nurse. Your studies in physiology and antotomy have informed you as to some of the functions of the body, and have prepared you for further stucly.

All of this knowledge is a valuable possession, but if your training lats cultivated and established in you the habit of elose, accurate observation, you have acquired something more important than all the rest. Your senses and pereeptions will be then so sharpened by constant use that you will cliscover, as by an instinct, the wants and needs of your patients. Fleeting signs that would escape an unobservant person will serve as guides for you in your care of the sick person, and you will have acquired that great gift of trained sympathy or tact which knows when to interfere and when to let alone. 'Then will you have reached the summit of the nursing art. You will save the strength of the feeble and will give courage to those that are atronger than they think. In this way are many feet turned back from the brink of the grave.

'To the physician too, the nurse's value depends largely upon her watchfulness. He is with his patient occasionally; the nurse is on the ground all of the time. She must serve, then, as eyes for the doctor, and he must learn many things about his patient from her observation and report. Every physician knows the comfort of feeling that the observation is correct and the report intelligent.

As I said in commeneing, the nursing art has alvanced with the advance in medicine, $\Lambda_{s}$ I believe, this advance in medicine is but now commencing. $1 \mathrm{am}$ of opinion that the training in nursing must be prepared for constant advance in the futurc. I believe that the two years usually given to the curriculum is already too short for a murse of moderate capacity to acquire the knowledge and training that she really ought to have. It would he better for our hospitals to have the nuise stay for a longer course; changes would come less frequently, and they would get, during the third year, some of the fruits of the drill which they have put into the first two year's of their training. It would, also, I am sure, be time well spent for the nurses. They would be far better equipped when they began their private work, and would easily show their superiority to those who had had a shorter training.

I should hope that in this longer course of study which I believe is coming in the near future, exereises would be devised which would train the nurse in making her own observations.

I well remember that when I began the study of natural history, Prof. Louis $\Lambda$ gassi\% put in my hand a dried coral, and told me to study it and learn about it from my own unaided observation all that I could. For many hours I sat turning this dried skeleton of a dead community over in $\mathrm{my}$ hand, and well remember the way in which its various characteristics gradually forced themselves upon my attention, and how the method of its growth slowly unfolded itself hefore me. That was an invaluable lesson and one which every observer ought to learn for himself.

There are abundant opportimities in the wards of every hospital for giving this sort of training, and I think it should be given in the manner that I have described, hy obliging the students to discover for themselves without help from their instructors. This sort of observation can and will be constantly exereised by you in your coming labor.

Do not tire of patient looking. You all have heard the old proverb and know why you have two eyes and only one tongue.

Use your eyes well first and only after thorough examination report what you have seen and ask, if you wish, its significance.

'The nurse who does this will commend herself to patient and doctor; will find success, and will spread the fame of the school from which she came. This is the best return she can make for the debt. slie owes.

I thank you all for your kind attention to these few thoughts upon the higher education of women. It is a subject we are all interested in, ancl we wish these young women success in their chosen profession.

\section{Brigiual Inticleg.}

\section{ALBUMOSURIA.'}

"Y GHAUNCEY IRA BURR, M.J. (IARV.); MH.H. (YALE), IOBR'TANI, MN.

Albumosumis is the term used to describe that condition in which albumoses are present in the urine. It is a pathological state, and its importance hats been but dimly appreciated till very recently. 'Together with albumosuria I shall also consider peptonuria, or the condition in which peptones are present in the urine. The line which divides the two is a very artificial one, and recent investigation has shown that many of the cases formerly described as peptonuria were, in reality, albumosuria, the real proteid present being denteroalbumose.

Albumoses are intermediate products in the digestion or hydration of proteids. 'There are four, to wit; proto-albumose, hetero-albumose, dys-allhumose and dentero-alhumose. The latter closely resembles peptone.

'The passage from one to the other is effected by hydrolytic cleavage, that is, by the absorption of water. If dentero-alloumose absorlos water it hecomes peptone, and if peptone absorlos water it is split up into the waste products of digestion, lencin, tyrosin, etc.

Iydrolysis in effeeted throngh the anency of a proteolytic ferment, or enzyme. When oceurring in the gastro-intestinal tanct, these ferments are furnisherl by glands attendaut thereto, as the gastric glands, the pancreas and the intestinal grlands. The spleen and liver probably have proteolytic powers also. In addition to these, there are the ferments furnished by the hacteria contained in the ingested food and drink. 'The number of bacteria which have been found to flourish in the intestinal

1 Real before the l'ortlanil Medlcal Club, Feb. 5, 1903. 
contents is already large, and their ranks are constantly growing. Some fifty varicties have been described. A certain number are undoubtedly always present in health, while in clisease, of course, the number mat be considerably augmented. Some of these ferments form sugar from starch, some peptone from proteid, while others disintegrate fats. If for any reason these products are not al)sorbed, digestion or rather disintegration may be c:arried to its later results. The sugar becomes lactic acid and alcohol; the peptone is replaced by the amido-acids, lencin and tyrosin, by skatol, indol and phenol; the fats split up into valeric acid, butyric acid, ete. It is thus evident that the hacteria found in the chyme are a very considerable aid to digestion thongh by no means an essential to the process.

Peptone is the final proluct of proteid digestien, and as such is absorbed. But here a very remarkable fact comes into view. Peptones and albumoses are both found in the chyme, but neither oceur in the normal blood. 'Their place in the latter is taken ly serum albumin. No medianical theory of absorption will account for this paradox. Peptones are diffusible and readily pass through animal membranes, and it is undonlitedly by virtue of this property that they are absorbed when and where they are. But the diffusion procects no farther. We are fare to face with a vital process.

The peptones are absorbed by the epithelial cells which cover the intestinal villi and also probably by the lencocytes, which during digestion crowd the lacteals and the submucous spaces. Within these cells (both leucocyte and epithelial) a reversible zymolysis or dehydration occur's, wherely the peptones are changed back again into albunin. The fact admits of no other interpretation. $\Lambda \mathrm{s}$ to the details of the process, considerable light has been furnished recently hy the work of physiologists. Jones and Hunt in (iould's "American Year Book of Medicine and surgery for 1902," say : "The law that the continual removal of one of the products of a chemic reaction causes its continual formation was known to Pronst in the carly part of the [nineteenth] century. Conversely the retarding action which is caused by the accumulation of the products of a chemic reaction is just as universally recognized. This law in itself would furnish an explanation of the failure of en\%ymes to produce complete hydrolysis, but in several instances it has been experimentally shown that the decompositions produced under the influence of enzymes do reach completion when the products of the reaction are removed as they are formed.

"Ilill, 2 however, gives an explanation of the law itself. II found that maltose not only decomposes maltose into dextrose, but is capable also of forming a synthesis of maltose from dextrose. Thus whenever dextrose or maltose is submitted to the influence of the en\%yme, the one is converted into the other till a certain condition of equilibrium has been established and no further decomposition follows. When, however, either one of these substances is removed, more of this must be formed at the expense of the other till equilibrium has again been establishel."

What Ilill has shown to be true of maltose, Kastle

2 Jouru. A II. Chem. Soc., Ixxlii, J. ti34. and Loewenhart ${ }^{3}$ have shown to be true of lipase (a new fat-spliting ferment). They not only decomposed ethyl-butyrate into its corresponding acid and alcohol, but ont of these, by the aid of lipase, they reconstructed ethyl-butyrate.

'The conditions for reversible zymolysis in the intestinal mucosa are very favorable. Peptones are continually being absorbed, and the equilibrium ean only be restored by the reconversion of these into albumin. As this is remover by the portal circulation, more peptones are absorbed. Just where the change occurs, whether in the epithelial cell or the leucocyte, or in both, has not, as yet, beell determined. But at all events I offer this suggestion of a reversible zymolysis in one or the other, as the explanation of an otherwise mexplainable phenomenou.

Albumoses, though present in the chyme, are never absorbed into the hlood under normal conditions. 'This is doubtless due to the fact that they are not diffusihle, that is, that they pass through animal membranes with diflieulty, and very slowly.

This is all changed, however, when there is a break in the continuity of the intestinal mucosa. They are then absorbed into the blond with ease and reappear in the urine.

Chrostek and stromayer " administered to patients free from albuminuria, but in whom either gatstric or intestinal ulceration was suspected, a micl-dily meal of one or two ounces of peptone or somatose (which is a patented preparation of beef albumoses), mixed with water or broth. After two or three hours, the urine was ex:mined for albumoses.

In six out of nine cases alloumosuria wats found to be present, and in every one of these tulserculous ulcers of the intestines were found at the necropsy.

On the other hand, a diet of albumoses administered to twenty healthy individuals failed to produce albumosuria in a single instance.

When once in the circulation, allumoses tend to remain there till further digested. 'They appear in the urine mostly as deutero-albumose and peptone. If proto-albumose or hetero-albumose are injected subcutaneously they are excreted as deutero-albumose; while if deutero-slbumose is injected, it is excreted as peptone.

Albumosuria may appear independently of or in connection with albuminuria. In fact, the latter condition of ten masks the former.

The intestinal tract is not the only source whence albumoses are derived.

Gillespie " believes that albumosuria is due to the excessive production and destruction of leucocytes.

Clinically, albumosuria is found where there is leucocytosis, and peptonuria where there is pus.

The lencocyte has a digestive ferment of its own, as shown by Rossbach and Leber, and is quite eapable of producing albumoses, as in the asse of a sterile abscess caused by hypodermic injections of croton oil, carbolic acid or ammonia water.

We also know that in the state in which leneocytosis occurs, there is nearly always a disturbance of the osmotic relations of the blood. The chlorides leave the serum for the eells, and the albumins and phosphates leave the cells for the serum. It is 
highly probable, therefore, that a large part of the albumoses present in the blood of febrile cases are clerived in this manner from the lencocytes.

Dead lencocytes are digested. This occurs in general where there is congulation necrosis, and the process is greatly assisted by the ferments of the pyogenic bacteria which may happen to be present. Pus consists of serum albumin, albumoses, peptones, leucin, tyrosin, cholestrin, etc.

Fleischer found albumoses in the medulla of normal bone - the breeding-place of the polynuclear lencocyte.

"anelger "produced albumosmria in dogs by the adininistration of pyrorlin. The albumosuria was soon obscured by albuminuria. There was also marked progressive anemin, and the bones were filled with lymphatic tissue.

\section{DETECYTION.}

Clinically it is not necessary to distinguish be tween the different forms of albumoses present in the urine.

For their detection I prefer the methods given by Ogden, ${ }^{7}$ which are as follows:

(1) 'Take a small portion of urine in a test tube, and warm gently - a precipitate appears which is reclissolved on boiling and reappears on cooling.

(2) Acidulate the urine with acetic acid, and add a few drops of a saturated solution of sodium chloride - a precipitate forms which disappears on heating and reappears on cooling.

(3) Acld a few drops of nitric acid to the urine in a test tube. If the acid is not in cxcess a precipitate is formed which disappears on boiling and reappears on cooling.

(4) Add acctic acid, avoiding an excess, and then add a few drops of a solution of potassium ferrocyanide $(1: 10)$. A precipitate is formed which disappears on boiling and reappears on cooling.

(5) Completely saturate the urine at boiling point with neutral ammonium sulphate; filter and wash the precipitate with saturated solution of ammonium sulphate. Iissolve the precipitate in water or dilute sodium chloride solution and apply the beuret test. If albumoses are present a rose color results.

The beuret test is commonly applied in cases of peptonuria. It is unreliable because not only peptones, but albumoses and urobilin respond to it as well.

The only sure test is to proceed as in No. is; that is, to saturate the urine (which should be aciol in reaction) with ammonium sulphate, filter out the precipitate, and and to the filtrate either potassiomercuric iodide or picric acicl. If a precipitate atpears it is peptone.

\section{PATHOLOKYY}

Albumosuraa occurs in a variety of conditions. Aldor ${ }^{8}$ found it present in almost $90 \%$ of febrile diseases. Krehl and Matthes ${ }^{9}$ found it of almost constant occurrence in both infectious and aseptic fevers. Other observers have found it in multiple myeolosarcoma, osteomalacia, carcinoma, tertiary syphilis, hemiplegia, pueumonia, diphtheria, muscu-

: Berlln klin. Woch., XXXV1I, s. 894.

iClin. Wxan. of Urlne and Urln. l)ag., 19xk, p. 133.

Arcli. f. exper. I'ath. U. l'harmakof, Band XLl, y. 218. lar atropy and myxedema; it has ahso been found in leukemia and after prolonged exertion and in many other diseases. Peptonmia has been observed in suppurative diseases, as empyema, chronic bronchial catarh and mixed tuberculosis, psoas abscens, purulent meningitis and acute articular rheumatism; it is also found in typhoid, typhus, variola, scarlet fever, mumps, erysipelas, carcinoma, catarrhal jaundice, apoplexy and pnemmonia.

In nearly all of these cliseases there is lencocytosis, and the degree of albumosuria (and peptonuria) may be expected to run parallel with this.

The pathology of the affection has not been exhatusted when the diseases in which it occurs hav been named. $\Lambda$ lbumoses are toxic, and the question may well be asked, and has been askerl, whether the symptom complex to which the term "fever" is applied may not be due to albumose poisoning. Krehl and Matthes and Aldor "1" are of the opinion that it is, and I am in thorough accord with them. Some of the deadliest toxines known are albumoses. Cobra venom consists of $98 \%$ of albumose and peptone and $2 \%$ of globulin. Its toxicity resides in the albumose.

'The primary albumoses are more toxic than the secondiry, and the peptones less toxic still. Pepsin itself is highly toxic.

Matthes showed that $.07 \mathrm{gm}$. of clentero-albumose injected subcutaneously produced in healthy men a marked febrile reaction. In three cases of lupus there was also a clecided local reaction exactly similar to that produced by tuberculin. Indeed, he considers tuberculin to be a mixture of cleuteroalbumose and peptone. As we approach the other end of the alhumose scale the symptoms increase in severity. 'Thus injections of primary allumoses give rise not only to fever, but to hemorrhagic: extravasations. The coagulability of the blood is lessened, secretion ceases and paralyses develop. There are neurotoxie: and hemolytic principles in allumoses just as there are in serpent venoms. They unite with the neurons and the blood cells readily and rapidly, and camnot he removed therefrom by chemical reagents as can morphia or strychnia.

The higher centers of the brain and cord appear to be specifically affected, and in particular those of the medulla oblongata. 'Thus, in febrile diseases the tongue is generally coated and the fauces parched and dry. Deglutition is more or less painful and diflicult, and there may be angina. The glosso-pharyngeal nerve supplies all these parts, and its origin is in the meclulla oblongata. Its impared function is the cause of these particular symptoms.

$\Lambda$ gain, the pnemmogastric nerve has its origin in the medulla. Paresis of this causes pulmonary congestion and dyspnea, a rapid pulse, impaireil motility of the stomach and dilatation, enlargement of the liver and spleen, and disordered digestion and absorption.

Sipace does not permit me to enlarge on the full pathology of albumose poisoning, but in general it is co-extensive with that of the septic state.

I wish, however, to and a few works as to the effect of albumoses on the blood. Most infectious diseases are accompanied by inflammatory leucocytosis. 'There is more or less anemia and a progress$10 \mathrm{Op}$. cit. 
ive loss of serum albumin. Coagulation may be $\quad$ into sodium and chlorine. The sodium unites with increased or retarded, and appears to be dependent carbon dioxide to form sodium carbonate and bicarupon the amount of hemoglobin dissolved in the bonate, and the chlorine is left free to exert its antiplasma. Degenerative changes in the erythrocytes, septic action.

whatever their nature, are believed to result in a dis- The normal salt solution may be given hyposociation of the hemoglobin from the stroma of the dermically, but I prefer rectal injections of a pint latter.

'The hemorrhagic extravasations and the lessened congulability of the blood which occur in albumose poisoning are the direct effeet of the hemolytic principle contained in the albumose. There is thus erythrolysis and possibly leucolysis. The anemin is thus accounted for.

The progressive loss of albumin is undoubtedly due to the increased metabolism of the body at large. The blood is dliwn upon heavily for food.

As the blood becomes hydremic, which it does in most fevers, the isotonic tension between the blood cells and the serum is entirely upset.

This has been particularly investigated with regard to erythrocytes, but I doubti not applies equally well to most of the soft tissue borly cells. 'To my mind it accounts for the emaciation which accompanies so many acute febrile disenses.

The osmotic law is that when two solutions of different concentration are separated by un animal membrane, the solutions pass through the membrane till the quantity of salt in each is equal.

In the case of erythrocytes, the chlorides pass from the serum to the cell, and the albumins and phosphates from the cell to the serum.

'The disappearance of chlorides from fever urines is thus explained, as well as the increased output of nitrogenous waste products, sulphates and phosphates.

\section{TRENTMENT.}

The treatment of albumosuria and peptonuria is, in general, that which is employed for the septic state. 'The most that we can do at present is to nentralize as far as possible the effects of the poison.

The neurotoxic element is best combated by oxygen and strychnia. Since albumoses form a chemical combination with the neurons, nothing short of an antitoxin will dislodge them. Antitoxins are cellular secretions. Such being the case, anything which increases cellular activity will, ceteris paribus, increase ccllular secretion. Oxygen is one of these substances. The living body cell is aerobic. $\Lambda$ gain, oxygen assists in the digestion of proteids, and particularly in the disintegration of peptones. The excretion of urea is increased uncler its use, and it is therefore a diuretic. I have tried various methods of administering oxygen, but the one from which I have seen most benefit is by the ingestion of a new chemical compound, magnesium dioxide, called "Biogen" by its pharmaceutical sponsors. This preparntion is claimed to contain $28 \%$ of oxygen.

Another agent of value is normal salt solution. It ought to be used much more frequently in septic states than is at present customary. It not only restores the isotonic tension of the blood where this has been disturbed and thereby prevents the drain of albumins and phospliates from the body cells, but is itself an antiseptic of no mean power. Soluor half a pint morning and night, the bowels having
previously been emptied by an enema.

The circulation improves under its use, but it is well to remember that an excess produces dyspnea, headache, cardiac pain and even pulmonary edema.

Where albumosuria is the result of an intestinal lesion, this of course must be treated by itself, and the same is true of any local collection of pus.

In closing, I would agrin call attention to the clinical fact that apart from lesions of the digestive tract, albumosuria is indicative of lencocytosis, and peptonuria of pus absorption.

Treatment based upon these indications cannot go far astray.

A CAST OF JUVENILE AOR'TIC S'IENOSIS, 'WI'III SUBSEQUEN'I' INSUFFICIENCY. SUDDEN DEA'TII : AU'TOPSY.

\section{BY ALBELT N. BLODGETT, M.D., BOSTON.}

Ine subject of this paper was a man of twenty years, who had been under my observation for a period of about two and a half years. He had always been "well," according to his own statement, though he belonged to a family which adheres to a peculiar sect which does not acknowledge the existence of disease, but occasionally recognize a "claim" of pneumonia, rheumatism, etc., so that statements in relation to his former health may not have been wholly reliable. His father died after a long illuess, with confiuement to the bed, of what was called "curvature of the spine." The mother and one brother are in good health. The patient was about five feet eight inches in stature, and his weight varied slightly around $150 \mathrm{lbs}$. He had been much devoted to athletics, and was interested in anything which related to muscular exercise. He was fond of boxing in particular, and rode the bicycle with much enthusiasm. His face was partially covered with stains due to grains of powder. His nose was somewhat distorted from an accident, and his left arm was slightly deformed from a reputed fracture of the ulna; but this in no way interfered with its free use, or restrained him from any of his favorite exercises. He had no regular occupation, and passed his time mainly in the pursuit of pleasure, which generally took the form of active muscular sport. He had dissipated to some extent, and pointed with an evident sense of pride to a depressed cicatrix on the glans penis, as proof of his claim to be called a "sport." He gave a very unsatisfying account of this lesion and its behavior; no rational history of treatment or of subsequent developments, and during the period while under my observation there were no symptoms of specific cliaracter.

My attention was attracted to the patient by a casual examination of the pulse, which was 58 to tions of sodium chloride are dissociated in the blood fairly regular, but was accelerated by any excite- 